\begin{tabular}{|c|c|c|}
\hline \multirow{2}{*}{\multicolumn{2}{|c|}{\begin{tabular}{l|l} 
DE & DE GRUYTER \\
OPEN
\end{tabular}}} & ECONOMIC THEMES (2017) 55(2): 263-280 \\
\hline & & DOI 10.1515/ethemes-2017-0015 \\
\hline
\end{tabular}

\title{
RELATIONSHIP OF AGES AND GENDER OF THE EMPLOYEES IN ORGANISATIONS IN THE REPUBLIC OF SERBIA AND THEIR JOB SATISFACTION
}

\section{Biljana Djordjević}

University of Nis, Faculty of Economics, Republic of Serbia

$\square$ biljana.djordjevic@eknfak.ni.ac.rs

Maja Ivanović-Djukić

University of Nis, Faculty of Economics, Republic of Serbia

$\bowtie$ maja.djukic@eknfak.ni.ac.rs

\section{Vinko Lepojević}

University of Nis, Faculty of Economics, Republic of Serbia

凶vinko.lepojevic@eknfak.ni.ac.rs

\section{UDC}

005.96(497.

11)

Original

scientific

paper

\begin{abstract}
The purpose of this paper is to investigate the relationship between ages and gender of employees in organisations in Serbia and their job satisfaction. When it comes to age-job satisfaction relationship the assumption is that this relationship could be represented by the "U" curve. When it comes to gender-job satisfaction relationship the authors investigate whether there is a difference in the overall job satisfaction between men and women as well as whether there is a statistically significant influence of different job facets on job satisfaction of men and women in different ages in organisations in Serbia. For testing these assumptions descriptive statistics and multivariate analysis of variance were applied. The research methodology also included theoretical analysis of the concept of job satisfaction. Results of the study have shown that the level of job satisfaction of employees of different age cannot be represented by the "U" curve. Further, the results have shown that there is a small difference in the overall job satisfaction between men and women as well as that there are some dimensions of job that have statistically significant influence on job satisfaction of men and women in different ages. The practical implication of this paper is that it, based on the obtained results, suggests to the managers certain human resource management (HRM) practices in order to gain more satisfied and, hence, more productive employees.
\end{abstract}


Received: 16.05.2017.

Accepted:

Keywords job satisfaction, age, gender, employees, organisations.

08.06.2017.

JEL classification: J10, J16

\section{Introduction}

There is no doubt that the most important resource of every organisation are human resources since they create and use other resources of the firm. Under certain conditions, this resource could even be the source of a sustainable competitive advantage of an organisation (Barney, 1991; Wright et al., 1993). Therefore, it is not surprising that employees competencies, attitudes and behaviour have occupied for decades the attention of authors from many fields.

By studying the employees`attitudes toward work and their behaviour in an organisation, many authors found out that human resources use their full potential towards achieving organisational goals when they are satisfied with their job $(\mathrm{Gu}$ \& Chi, 2009; Kuzey, 2012; Latif et al., 2013). In the case of high job satisfaction it was also found that they may demonstrate many other positive forms of behaviour, such as organisational citizenship behaviour (Farrel, 1983), organisational commitment (Azeem, 2010), low turnover intentions (Crasten \& Spector 1987), etc. Since this phenomenon is connected with many important outcomes in a workplace it is not surprising that this topic is one of the most investigated in the literature whose tradition of research dated till the 1930s and famous the Hawthorne experiment (Judge et al., 2001, p. 376).

Job satisfaction as a phenomenon could be seen as a global feeling about a job or it can be seen as a constellation of the attitudes about various aspects of a job (Spector, 1997). But, nevertheless whether the job satisfaction is seen as a global phenomenon, or as a composition of various feelings about various aspects of a job, this phenomenon could be moderated by various variables associated with employees, such as level of education (Clark, 1996; Wharton et al. 2000; Koys, 2001), career stage (Cron \& Slocum, 1986), gender (Clark, 1997; Lee, 2012), ages (Herzberg et al., 1957; Handyside, 1961; Clark, 1996; Clark, Oswald \& Warr, 1996, Bernal et al., 1998), etc. Therefore, understanding the nature of job satisfaction requires taking into account many demographic, situational and other variables associated with employees.

For the purpose of this paper, the authors will investigate whether ages of employees in organisations in Serbia have moderating influence on their job satisfaction and whether this relationship could be represented by the "U" curve as it was found in some studies conducted so far. The authors will also investigate whether there is a difference in the overall job satisfaction between men and women in organisations in Serbia as well as whether there is statistically significant 
influence of different job facets on their job satisfaction since in this country there are still differences in the social roles between men and women (Položaj žene $\mathrm{u}$ Srbiji u 2014 - činjenice koje demantuju stavove, 2014). In order to test these assumptions, primary research was conducted. The sample included 813 employees in organisations in Serbia, mostly at the south-east of the country. The research methodology also included theoretical analysis of the concept of job satisfaction, descriptive statistics and multivariate analysis of variance.

The paper is organised as it follows. Firstly, the authors will give an overview of the literature on job satisfaction and starting hypotheses. In the second part of the paper the authors will explain the methodology and obtained results. The final part of the paper presents concluding remarks and limitations of the study.

\section{Literature Review and the Research Hypothesis}

Job satisfaction is usually seen as "a pleasurable or positive emotional state resulting from the appraisal of one`s job or job experiences” (Locke, 1976, p. 1304). Job satisfaction could also be defined as a result of a cognitive, affective and evaluative reaction of an individual on various dimensions of job (Judge at al., 2001). Spector (1997), further, states that job satisfaction could be seen as a global feeling about the job or it can be seen as a constellation of the attitudes about various aspects of job such as nature of job, pay, possibilities for promotion, relationship with co-workers and supervisors, etc. (Spector, 1997). Therefore, this author concluded that two approaches regarding the nature of job satisfaction could be identified: the global approach and the facet approach. He states that the global approach is useful when overall attitude about a job is in the focus or when one wishes to determine the effects of people liking or disliking their job. On the other hand, the facet approach is useful when organisations wish to find out which part of the job produce satisfaction or dissatisfaction of the employees, or when they wish to identify areas of dissatisfaction that they can improve (Spector, 1997).

Very useful notion for understanding the nature of job satisfaction is the opinion that job satisfaction represents the level of divergence between what a worker expects to receive and what he/she actually experience in the workplace (McShane, 2004). In that line, Fako et al. (2009) state that if one expects little and gets little, he/she would be satisfied as much as one who expects a lot and gets a lot. On the other hand, if one expects a lot and gets little, he/she would be dissatisfied (Fako et al., 2009). Here, one should also add the fact that employees might be satisfied with some parts of their job, while at the same time they may be dissatisfied with others (McShane, 2004).

The complexity of job satisfaction could also be seen from the fact that many instruments for investigating and measuring the influence of some part of the job on overall job satisfaction have been developed so far. At the same time variety of 
these instruments and aspects of a job that can be measured show that there is no "gold standard" about which job aspects should be taken into account when job satisfaction is measured (van Saane et al., 2003). However, in this paper the authors implement Spector`s nine facets approach regarding the causality of job satisfaction. According to this author, job satisfaction could be influenced by the following nine dimensions of a job: pay, promotion, fringe benefits, contingent reward, supervision, co-workers, operating procedures, nature of work and communication (Spector, 1985).

Besides the fact that there are plenty of job facets which might influence the job satisfaction of employees, there are also plenty of factors that may have an impact on which particular aspect of the job will have an importance for them. As it was earlier said, in many studies it was found that job characteristics - job satisfaction relationship could be influenced by variables such as level of education, demographic characteristics of employees, psychological personality characteristics of employees, stage of career development, etc. Since the aim of this paper is to investigate the influence of age and gender of employees on the job satisfaction, in the further sections the authors will give an overview of the literature which refers only to the influence of these variables on job satisfaction.

\subsection{Job Satisfaction and Ages of Employees}

Literature of age generally tends to focus on the norms, values, and social roles associated with employees of different age (Novak, 1993). When it is about the relationship between ages of employees and job satisfaction many studies have been conducted so. However, the results are mixed. In that line Bernal et al. (1998) identified five possible relationships, such as: positive linear relationship (Hunt \& Saul 1975), negative linear relationship (Muchinsky, 1978), "U" shaped relationship (Herzberg, 1957, Handyside, 1961; Clark, Oswald \& Warr, 1996, Clak, 1996), inverted "U" relationship (Saleh \& Otis, 1964) and no significant relationship (White \& Spector, 1987).

One of the first findings regarding the relationship between age and job satisfaction is that this relationship could be represented by the " $U$ " curve. The explanations why this type of relationship occurs are seen for the following reasons. First, older employees usually have specific work values (stability, security) which make more attractive some job characteristics that are less desirable to younger people. On the other hand, income and promotion opportunities tend to be of greater importance for younger workers (Clark et al., 1996). Therefore, Clark et al. (1996) conclude that if employees, in general, tend to be relatively dissatisfied with these characteristics, then the greater importance of income and promotion for younger workers will result in a positive relationship between age and job satisfaction. Further, the "U" curve could also be explained by the fact that the older workers during lifetime gain real experience which tend to 
lower their expectations regarding the job. Therefore, during the time, the gap between reality and expectations tends to be lower and lower, so this situation can produce their higher job satisfaction. On the other hand, very young employees are usually very exciting and satisfying with their job since being employed provides them the opportunity to gain financial resources for living on their own. Clark et al. (1996) also state that high job satisfaction of very young employees could be explained by the fact that they "may have not enough information about the world of work to know whether their job is good or bad in relation to others" (Clak et al., 1996, p. 76). However, if the expectations of young employees are not met during the time, their job satisfaction could become lower. This particularly could be characteristics of employees in the maintenance career stage when they realised that they could not achieve their ambitions.

Based on the above text the following hypotheses are proposed:

H1: The relationship between age and job satisfaction of the employees in organisations in Serbia could be represented by the " $U$ " curve,

H2: There are significant differences in the impact of certain dimensions of the job on job satisfaction of employees of different ages in organisations in Serbia.

\subsection{Job satisfaction and gender}

There are also numerous studies that investigated the influence of gender on job satisfaction. The results of these studies are also very contradictory. In some studies it was found that there is not statistically significant difference in the job satisfaction between men and women (Golembiewski, 1977; Eskildsen et al, 2003). In others, it was found that women, compared to men, were more satisfied with their job (Clark 1997; Wharton et. Al., 2000), while in some studies the results were the opposite (Forgionne \& Peeters, 1982).

It was found, for example, that men expressed higher job satisfaction in organisations where they had more opportunities for advancement or where women are last to be employed and the first to be fired (Bendall-Lyon \& Powers, 2002). On the other hand, it has been found that in societies in which women are in a disadvantaged position in the labour market, that they were more satisfied with their job than men were. This phenomenon in the literature has been recognised as some kind of paradox (Lee, 2012). The explanation for this can be seen in the following reason: the disadvantaged position of the women in the labour market makes them have low expectations from work (Sousa-Poza and Sousa-Poza, 2000), so the gap between their expectations and the reality is very small, which consequently results in their relatively high job satisfaction.

Generally speaking, the job satisfaction of women is usually set up by different factors comparing to men`s job satisfaction (Bender et al., 2005) since their values 
and social roles in family and society are usually different. For example, in most societies, a psychosocial responsibility of women toward family is greater than of men`s and women have much greater involvement in conducting family duties. On the other hand, the economical responsibility of men for a family is usually higher than that of women`s (Clark, 1997). Therefore for women, it is usually more important to have flexible working hours and perform an interesting job than to have high wages or possibilities for promotion.

When it comes to Serbia the investigations show that the overall socioeconomic status of women is worse compared to men `s in the area of employment and other aspects of life (Pozicija žene u Srbiji u 2014 - činjenice koje demantuju stavove, 2014). Therefore, the authors of the paper assumed that men and women in organisations in Serbia may have different expectations regarding the job and employment which may lead to the fact that different aspects of job have significant influence on their job satisfaction.

Based on the previously text the authors propose the following hypotheses:

H3: There are differences in the overall job satisfaction between men and women in organisations in Serbia,

H4: There are differences in job satisfaction between men and women of different ages in organisations in Serbia,

H5: Job facets that have statistically significant influence on job satisfaction of men and women in different ages in organisations in Serbia are different.

\section{Method}

Sampling method and data collection. In order to test previously mentioned hypotheses, the primary research was conducted. The research was carried out in the period from June to September 2016 by distributing the quesitonares in written form in organisations at the south-east of Serbia. One part of the questionnaire included questions related to general information about the respondents: gender, age, years of service, the level of education, and position in the organisational structure. The second part of the questionnaire included questions related to job characteristics which influence their job satisfaction.

Sample characteristics. The study initially included 1000 respondents, employed in 28 organisations operating. Out of 1000 distributed questionnaires, 813 were usable, while 187 questionnaires were rejected due to inaccurate or incomplete answers. In the structure of the sample, females accounted for $42.8 \%$, while the share of men was $57.2 \%$. Regarding the age structure, the situation was as it follows: $24.7 \%$ were the respondents younger than 30 years, $28.8 \%$ are between 31 and 40 years, 30.7\% of respondents were between 41 and 50 years, while the share of the respondents older than 50 years amounts to $15.8 \%$. 
As far as years of service are concerned, the employees between 6 and 15 years of service had the highest share in the sample, amounting to $33.9 \%$, followed by the employees with less than five years of service, amounting to $26.9 \%$. The somewhat lower share was held by the employees between 16 and 25 years of service, $25.5 \%$, whereas the lowest share was held by the employees with more than 26 years of service, $17.7 \%$. According to the results of the research, the highest share in the sample have the employees who have a high school, amounting to $53,1 \%$, followed by the employees with high education amounting to $42,4 \%$. The lowest share in the sample have the employees with the elementary school, amounting to $3,7 \%$ and those who hold a $\mathrm{PhD}$, amounting to $0,7 \%$.

Research variables and instruments. In order to measure employees` job satisfaction Spector`s Job Satisfaction Survey (JSS) (Spector, 1985) is used. This questionnaire is designed to assess employee attitudes towards nine aspects of a job that could influence job satisfaction, such as pay, promotion, fringe benefits, contingent rewards, supervision, co-workers, operating procedures, nature of work and communication. Each aspect of job is assessed with four items (Spector, 1985) by using the five-point Likert scale, ranging from 1 - strongly disagree, to 5 strongly agree. An answer of 4 or more points expresses satisfaction, while answers of 3 points express a neutral opinion and below 3 points express dissatisfaction.

Since the questionnaire has reverse questions during the analysis a reversal of initial coding was applied, so that in all questions, high scores indicate great degrees of satisfaction, and vice versa.

In order to measure the impact of ages on job satisfaction 4 categories are used: employees aged up to 30 years are represented by number 1 , employees aged between 31-40 years are represented by number 2, employees aged between 41-50 are represented by number 3 and employees aged over 51 years are represented by number 4.

Analyses and procedures. Data analysis was carried out in several steps. First, the appropriate descriptive measures were used. To check the validity of the hypothesis multivariate analysis of variance is used. The data were analysed with the SPSS 17.0 programme.

\section{Results and Discussion}

Cronbach's Alpha value of 0.906 indicates a very good compatibility of the questions in the questionnaire for a given sample. According to the data from Table 1 , for column Correlated Item-Total Correlation, there is a high degree of correlation of each item with the overall results. Since all the values in the column Cronbach's Alpha if item Deleted are less than the final value of alpha (0.906), we find that it is advisable that all items in the existing scale remain, and that this scale 
is comparable to other studies which are based on such a scale. Also, the mean correlation value between the items is 0,513 , and correlation between pairs of items is from 0,384 to 0,767 , indicating strong correlation between items.

Table 1. Item-Total Statistics

\begin{tabular}{lcc}
\hline \multicolumn{1}{c}{ Domain } & $\begin{array}{c}\text { Corrected Item-Total } \\
\text { Correlation }\end{array}$ & $\begin{array}{c}\text { Cronbach's Alpha if Item } \\
\text { Deleted }\end{array}$ \\
\hline Pay &, 809 &, 886 \\
Promotion &, 795 &, 886 \\
Fringe benefits &, 721 &, 892 \\
Contingent rewards &, 641 &, 899 \\
Supervision &, 621 &, 900 \\
Co-workers &, 809 &, 886 \\
Operating procedures &, 440 &, 905 \\
Nature of work &, 558 &, 901 \\
Communication &, 748 &, 891 \\
\hline Crnbach's Alpha &, 906 & \\
\hline Valid N & 813 & \\
\hline
\end{tabular}

Source: Authors.

For checking the existence of significant differences in impact of ages on job satisfaction multivariate analysis of variance was applied. The results are shown in Table 2.

Table 2. Multivariate Tests

\begin{tabular}{llrrrrr}
\hline & & \multicolumn{3}{c}{ Hypot. } & & \multicolumn{1}{c}{ Value } \\
Intercept & Pillai's Trace &, 978 & 3976,74 & 9 &, 000 &, 978 \\
& Wilks' Lambda &, 022 & 3976,74 & 9 &, 000 &, 978 \\
& Hotelling's Trace & 44,683 & 3976,74 & 9 &, 000 &, 978 \\
& Roy's Largest Root & 44,683 & 3976,74 & 9 &, 000 &, 978 \\
\hline Age & Pillai's Trace &, 124 & 3,833 & 27 &, 000 &, 041 \\
& Wilks' Lambda &, 881 & 3,845 & 27 &, 000 &, 041 \\
& Hotelling's Trace &, 130 & 3,855 & 27 &, 000 &, 042 \\
& Roy's Largest Root &, 070 & 6,248 & 9 &, 000 &, 065 \\
\hline
\end{tabular}

Source: Authors. 
The observed set of multivariate significance tests given in Table 2 indicates that the groups are statistically different. Namely, the information related to the central MANOVA null hypothesis about the existence of differences between the groups are presented in this table. All p-values, with the exception of Roy's Largest Root, are less than 0,05 , which is the clear confirmation that the null hypothesis about the nonexistence of differences regarding the respondents` attitudes observed by age could be rejected. After checking the assumptions related to the implementation of the MANOVA - adequate sample size, absence of multivariate outliers, multivariate normality, linear relationship between each pair of dependent variables, homogeneity of variance-covariance matrices, multicollinearity, the authors concluded that conditions for testing are fulfilled. Data analysis was carried out in several steps. First, the appropriate descriptive measures are used. To check the validity of hypotheses a multivariate analysis of variance was used. The results are shown in Table 3.

Table 3. Multivariate analysis of variance - Age and job satisfaction

\begin{tabular}{|c|c|c|c|c|c|c|c|c|}
\hline \multirow{2}{*}{$\begin{array}{l}\text { Subscale of } \\
\text { satisfaction }\end{array}$} & \multicolumn{4}{|c|}{ Age } & \multirow[t]{2}{*}{$\mathbf{F}$} & \multirow{2}{*}{$\begin{array}{c}\text { p- }^{-} \\
\text {value }\end{array}$} & \multirow{2}{*}{$\begin{array}{l}\text { Partial } \\
\text { Eta Sq. }\end{array}$} & \multirow[t]{2}{*}{ Bonferroni } \\
\hline & 1 & 2 & 3 & 4 & & & & \\
\hline Pay & 3,96 & 3,68 & 3,80 & 3,96 & 3,42 & ,012 - r & ,013 & $1-2$ \\
\hline Promotion & 3,76 & 3,43 & 3,60 & 3,52 & 3,08 & ,007 & ,011 & $1-2$ \\
\hline Fringe benefits & 4,16 & 3,96 & 3,83 & 4,07 & 3,84 & ,009 & ,014 & $1-3$ \\
\hline Contingent rew. & 4,28 & 4,26 & 4,21 & 4,02 & 1,94 & NS & ,007 & - \\
\hline Supervision & 3,83 & 3,83 & 3,96 & 3,95 & 1,07 & NS & ,004 & - \\
\hline Co-workers & 3,94 & 3,81 & 3,89 & 3,97 & 1,03 & NS & ,004 & - \\
\hline Operating proc. & 3,83 & 3,78 & 3,78 & 3,55 & 4,05 & ,007 & ,015 & $1-4,2-4,3-4$ \\
\hline Nature of work & 3,59 & 3,48 & 3,44 & 3,32 & 5,00 & ,002 & ,018 & $1-4$ \\
\hline Communication & 3,91 & 3,75 & 3,86 & 3,65 & 1,63 & NS & ,006 & - \\
\hline Total satisfaction & 3,92 & 3,71 & 3,82 & 3,78 & & & & \\
\hline $\mathrm{N}$ & 201 & 234 & 249 & 129 & & & & \\
\hline
\end{tabular}

According to the results of the analysis (Table 3) it can be concluded that there is a certain impact of age on degree of job satisfaction of the employees in organisations in Serbia. The data show that the highest level of job satisfaction shows the category of the employees who belong to the age group up to 30 years $(A j s=3,92)$. Further, the data show that the level of job satisfaction of the next group of employees (Age group 2, 31-40 years) is lower than the job satisfaction of the previous group as well as that job satisfaction of this group of employees is the 
lowest one in comparison with the job satisfaction of all other groups of empolyees $(A j s=3,71)$. Data also show that the level of job satisfaction of employees aged 4150 (Age group 3) is higher in comparison with the previous group (Ajs=3,82), while the job satisfaction of the employees aged 51 and over (Age group 4) is lower than the job satisfaction of the previous group of employees (Ajs=3,78).

According to these results it can be concluded that the level of job satisfaction of the employees of different ages in organisations in Serbia could not be represented by the "U" curve, so the hypothesis H1 is not confirmed. This type of relationship could be identified only if the attitudes of job of the first three groups of employees are analyzed. However, this was not the starting assumption.

According to the data from Table 3 and having in mind the hypothesis $\mathrm{H} 2$ (There are significant differences in the impact of certain dimensions of job on job satisfaction of employees of different ages in organisations in Serbia), it can be concluded that the attitudes of the respondents observed by their ages do not differ significantly in terms of contingent rewards, relationship with supervision and relationship with co-workers as well as communication. The data show that age affects the respondents' attitudes about all other aspects of job satisfaction (pay, promotion, operating procedures and nature of work). More precisely, when it comes to pay the data show that there is a difference in the attitudes between the first (Age 1) and the second category of age (Age 2); when it comes to the promotion it can be seen that there are also differrent attitudes of the respondents who belong to the first and the second category of age; when it comes to contingent rewards there is a difference in attitudes of the employees of the first (Age 1) and the third category of age (Age 3); in terms of operating procedures there are distinctions in the degree of satisfaction of the respondents who belong to the fourth category of age (Age 4) and other three categories; and at the end, when it comes to the nature of work, there is a different degree of satisfaction of respondents who belong to the first (Age 1) and the fourth age group (Age 4). The Table 3 also show that the largest contribution to the differences in the attitudes of respondents observed by age, are the attitudes towards nature of work, while the least impact has the attitutude regarding the promotion.

Based on the above text it can be concluded that the hypothesis H2 is partly confirmed. It is confirmed only when it comes to the influence of the job facets such as pay, promotion, operating procedures and nature of work. In other words, only these job facets have statistically significant influence on the job satisfaction of the employees in organisations in Serbia of different age.

In the further text the analysis is deepened with introducing the gender variable in order to check whether there are differences in job satisfaction between men and women in organisations in Serbia. The results for men and women are shown in the Table 4. 
Table 4. Multivariate analysis of variance - Job satisfaction and gender

\begin{tabular}{|c|c|c|c|c|c|}
\hline \multirow{2}{*}{$\begin{array}{l}\text { Subscale of } \\
\text { Satisfaction }\end{array}$} & \multicolumn{2}{|c|}{ Gender } & \multirow[t]{2}{*}{$\mathbf{F}$} & \multirow{2}{*}{$\begin{array}{c}\text { p- } \\
\text { value }\end{array}$} & \multirow{2}{*}{$\begin{array}{l}\text { Partial Eta } \\
\text { Sq. }\end{array}$} \\
\hline & Men & Women & & & \\
\hline Pay & 3,887 & 3,767 & 2,684 & NS & ,003 \\
\hline Promotion & 3,616 & 3,539 & 0,905 & NS & ,001 \\
\hline Fringe benefits & 4,077 & 3,871 & 7,320 & ,007 & ,009 \\
\hline Contingent rewards & 4,271 & 4,147 & 2,822 & ,043 & ,003 \\
\hline Supervision & 3,832 & 3,974 & 4,033 & ,045 & ,005 \\
\hline Co-workers & 3,503 & 3,884 & ,085 & 0,03 & ,000 \\
\hline Operating proc. & 3,787 & 3,728 & 1,224 & NS & ,002 \\
\hline Nature of work & 3,535 & 3,388 & 10,389 & ,001 & ,013 \\
\hline Communication & 3,365 & 3,741 & 2,179 & NS & ,003 \\
\hline Total satisfaction & 3,863 & 3,782 & & & \\
\hline Pay & 237 & 176 & & & \\
\hline
\end{tabular}

Source: Authors.

As it can be seen in Table 4 the average job satisfaction is slightly higher among men $(3,863)$ than among women $(3,782)$. Furthermore, it can be seen that there are significant differences in the influence only the following job dimensions on job satisfaction of men and women: fringe benefits, contigent rewards, relationships with supervisors and co-workers and nature of work. Therefore, it can be concluded that the hypothesis H3 is partially confirmed.

In the further text the analysis of whether there are differences in job satisfaction between men and women of different ages in organisations in Serbia is presented. The analysis was first done for men. These results are shown in the Table 5.

Table 5. Multivariate analysis of variance - Age of men and job satisfaction

\begin{tabular}{|c|c|c|c|c|c|c|c|c|}
\hline \multirow{2}{*}{$\begin{array}{l}\text { Subscale of } \\
\text { Satisfaction }\end{array}$} & \multicolumn{4}{|c|}{ Age of men } & \multirow[t]{2}{*}{$\mathbf{F}$} & \multirow{2}{*}{$\begin{array}{c}\text { p- } \\
\text { value }\end{array}$} & \multirow{2}{*}{$\begin{array}{l}\text { Partial } \\
\text { Eta Sq. }\end{array}$} & \multirow[t]{2}{*}{ Bonferroni } \\
\hline & 1 & 2 & 3 & 4 & & & & \\
\hline Pay & 3,93 & 3,81 & 3,89 & 3,95 & ,455 & NS & ,003 & - \\
\hline Promotion & 3,73 & 3,56 & 3,59 & 3,55 & ,644 & NS & ,004 & - \\
\hline Fringe benefits & 4,20 & 4,13 & 3,83 & 4,11 & 2,607 & NS & ,017 & - \\
\hline Contingent rew. & 4,31 & 4,34 & 4,20 & 4,18 & ,687 & NS & ,004 & - \\
\hline Supervision & 3,76 & 3,85 & 3,91 & 3,82 & ,502 & NS & ,003 & - \\
\hline Co-workers & 3,88 & 3,97 & 3,87 & 3,88 & ,297 & NS & ,002 & - \\
\hline
\end{tabular}




\begin{tabular}{|c|c|c|c|c|c|c|c|c|}
\hline Operating proc. & 3,80 & 3,83 & 3,84 & 3,63 & 1,933 & NS & ,012 & - \\
\hline Nature of work & 3,65 & 3,57 & 3,44 & 3,41 & 3,880 & ,009 & ,025 & $1-3,1-4$ \\
\hline Communication & 3,87 & 3,75 & 4,11 & 3,75 & 2,328 & NS & ,015 & - \\
\hline Total satisfaction & 3,90 & 3,87 & 3,85 & 3,81 & & & & \\
\hline $\mathrm{N}$ & 135 & 141 & 105 & 84 & & & & \\
\hline
\end{tabular}

*NS - Non-significant

Source: Authors

The next table shows the data regarding the job satisfaction of women in organisations in Serbia.

Table 6. Multivariate analysis of variance - Age of women and job satisfaction

\begin{tabular}{|c|c|c|c|c|c|c|c|c|}
\hline \multirow{2}{*}{$\begin{array}{l}\text { Subscale of } \\
\text { Satisfaction }\end{array}$} & \multicolumn{4}{|c|}{ Age of women } & \multirow[t]{2}{*}{$\mathbf{F}$} & \multirow{2}{*}{$\begin{array}{l}\text { p- } \\
\text { val. }\end{array}$} & \multirow{2}{*}{$\begin{array}{c}\text { P.Eta } \\
\text { Sq. }\end{array}$} & \multirow[t]{2}{*}{ Bonferroni } \\
\hline & 1 & 2 & 3 & 4 & & & & \\
\hline Pay & 4,02 & 3,50 & 3,75 & 4,00 & 4,305 & ,005 & ,036 & $1-2,4-2$ \\
\hline Promotion & 3,82 & 3,24 & 3,63 & 3,47 & 4,067 & ,007 & ,034 & $1-2$ \\
\hline Fringe benefits & 4,09 & 3,71 & 3,83 & 4,00 & 1,889 & NS & ,016 & - \\
\hline Contingent rew. & 4,23 & 4,16 & 4,23 & 3,73 & 2,651 & ,049 & 023 & $3-4$ \\
\hline Supervision & 4,00 & 3,81 & 4,00 & 4,20 & 1,800 & NS & 015 & - \\
\hline Co-workers & 4,07 & 3,58 & 3,91 & 4,17 & 6,018 & ,001 & 050 & $1-2,2-3,2-4$ \\
\hline Operating proc. & 3,91 & 3,71 & 3,75 & 3,43 & 3,204 & ,023 & ,027 & $1-4$ \\
\hline Nature of work & 3,47 & 3,36 & 3,44 & 3,16 & 2,570 & NS & 022 & - \\
\hline Communication & 4,00 & 3,77 & 3,69 & 3,47 & 2,048 & NS & ,018 & - \\
\hline Total satisfaction & 3,96 & 3,65 & 3,80 & 3,74 & & & & \\
\hline $\mathrm{N}$ & 66 & 93 & 144 & 45 & & & & \\
\hline
\end{tabular}

According to data from Table 5, it can be concluded that the highest level of job satisfaction shows the category of the youngest men (age group up to 30 years, Ajs $=3,90)$ and that the job satisfaction further decreases with increase in the ages (Age 2=3,87, Age 3=3,85, Age 4=3,81). At the same time, the data from Table 5 show that there are not large variations in the level of job satisfaction among men of different ages.

When it comes to the women the data from Table 6 also show that there are variations in job satisfaction of women of different ages. Also, the data show that these variations are larger than the variations in job satisfaction of men. Table 6 
also shows that the highest level of job satisfaction has the category of the youngest women (age group up to 30 years, $A j s=3,96$ ) and that it is higher compared to the men's highest average job satisfaction $(\mathrm{Ajs}=3,90)$. But the surprising result is that the smallest level of job satisfaction is among women aged between 31-40 years $(A j s=3,65)$ and that their job satisfaction is far lower compared to the men's lowest average job satisfaction (Ajs=3,81). This can be explained by the fact that women between ages of 30 and 40 usually have small children to look after and that they in this period of life can not progress in their career. For example, they are extremely dissatisfied with the promotion opportunities $(\mathrm{Ajs}=3,24)$.

Having in mind previously results, it can be concluded that hypothesis $\mathrm{H} 4$ is confirmed, i.e. there are differences in job satisfaction between men and women of different ages in organisations in Serbia.

The data from Table 5 also show that nature of work is the only dimension which has statistically significant impact on job satisfaction of men in different ages. However, this difference is significant only among the youngest men and the men over 40 years (Bonferroni 1-3, 1-4). When it comes to the women the data from Table 6 show that there are more dimensions of job that have the statisticaly significant influence on job satisfaction of women in a different age. Data in this table also show that contingent rewards are the dimension that the most contributes to women's job satisfaction, but the impact of this dimension on job satisfaction is the greatest for the youngest women (Age group 1, up to 30 years) as well as for women aged between 41-50, while the least importance has for the women over 50 years. Pay, promotion and operating procedures are also dimensions which have a stronger influence on job satisfaction of the youngest women (Age group 1, up to 30 years) compared to the women's job satisfaction in other periods of life. Pay and promotions have the lowest influence on job satisfaction of women aged between 31-40 years while operating procedures has the lowest influence on job satisfaction of women over 50 years. For women aged 31-40 years, contingent rewards, relationship with supervisors and fringe benefits have significant influence on job satisfaction. The similar situation is with women aged between 41-50 years: for job satisfaction of this category of women, relationship with coworkers is also very important. Finally, the relationship with co-workers as well as with supervisors are dimensions which have the highest influence on job satisfaction of the oldest women (aged over 50 years). At the same time, relationship with co-workers is the dimension which is the more important for job satisfaction of the oldest women comparing to the women of other age groups.

Based on the previous text it can be concluded that the hypothesis $\mathrm{H} 5$ is confirmed, i.e. job facets that have statistically significant influence on job satisfaction of men and women in organisations in Serbia in different age are different. The job facet that has statistically significant influence on job satisfaction of men is nature of work, while the job facets that have statistically significant 
influence on job satisfaction of women are pay, promotion, contingent rewards, relationship with a co-worker and operating procedures.

According to the results presented in the previous text, it can be concluded that there are more dimensions of job that have statistically significant influence on job satisfaction of women probably because of the complex roles they have in their families as well as high expectations regarding the job.

\section{Conclusion}

Job satisfaction is a very complex phenomenon which can be influenced by the various types of factors. Different and sometimes contradictory findings regarding their influence confirm that this area still requires many answers.

In this paper, the authors investigated the influence of two variables on job satisfaction: ages and gender of the employees in organisations in Serbia. The results have shown there are differences in the level of overall job satisfaction of employees of different age in organisations in Serbia. However, this relationship could not be represented by the "U" curve as it is assumed in the paper. The results have also shown that there is a small difference in the overall job satisfaction between men and women

Besides the global approach regarding the job satisfaction, the facet approach was implemented as well. In that line, the study has shown that there are statistically significant differences in dimensions of job which influence job satisfaction of men and women in a different period of their life (ages). When it comes to the men of different age the study has shown that nature of work is the only dimension which has statistically significant impact on their job satisfaction (though this difference is significant only among the youngest men and men over 40 years). On the other side, the study has shown that there are statistically significant differences in the influence of much more dimensions of job on job satisfaction of women of different ages. Statistically significant influence on job satisfaction of women of different ages has pay, promotion, contingent rewards, relationship with co-workers and operating procedures.

At the final, the authors of the paper are aware of the limitations of the study especially regarding the representativeness of the sample. First, in the investigation only the organisations from one part of the country were included so the answers of the respondents may not be the representative ones. Second, the structure of the sample regarding the gender is not in the line with the actual structure of employees in organisations in Serbia which also contributes that the sample is not the representative one.

However, the authors hope that this topic will be interesting for the audience, especially for managers, in order to better understand this complex issue and to 
consider implementing those HRM practices which will produce more satisfied and, hence, more productive employees.

Having in mind the obtained results the authors especially recommend the following HRM practices:

- Since the nature of work is very low accessed by the employees, in order to make job routine more interesting and challenging, job redesign could be one of the solutions,

- The appropriate measure could also be a better redeployment of the employees which could provide that job tasks correspond better with the competencies of the employees,

- Since the lowest satisfaction with the nature of work expressed older workers (both men and women) introducing mentoring programs through which they could teach and supervise the progress of the young employees could make their job routine more interesting and challenging,

- Since the employees are not satisfied with the communication in organisations management should establish better communicational channels and be more available to respond to the employees` questions and concerns,

- Having in mind that employees in organisations in Serbia are not satisfied with the promotion practices the authors recommend establishing more objective criteria for this purpose. In other words, those who are better in performing the job and have other necessary competencies should be in advantaged position when it is about making the decision on promotion.

Since the women are especially dissatisfied with promotional practices in organisations in Serbia proper measure in this area should also be eliminating potential discrimination upon gender.

\section{References}

Azeem, S. M. (2010). Job satisfaction and organizational commitment among employees in the Sultanate of Oman. Psychology, 1 (4), 295-300.

Barney, J. (1991). Firm Resources and Sustained Competitive Advantage. Journal of Management, 17 (1), 99-120.

Bendall-Lyon D. \& Powers, T. L. (2002). The impact of gender differences on change in satisfaction over time. Journal of Consumer Marketing, 19 (1), 12-23.

Bender, K. A., Donohue, S. M. \& Heywood J. S. (2005). Job Satisfaction and Gender Segregation. Oxford Economic Papers, 57 (3), 479-496.

Bernal, D., Snyder, D. \& McDaniel, M. (1998). The age and job satisfaction relationship: Does its shape and strength still evade us? Journal of Gerontology: Psychological Sciences, 53B (5), 287- 293. 
Carsten, J. M. \& Spector, P. W. (1987). Unemployment, job satisfaction, and employee turnover: A meta-analytic test of the Muchinsky model. Journal of Applied Psychology, 72 (3), 374-381.

Clark, A. E. (1996) Job satisfaction in Britain. Journal of Industrial Relations, 32 (4), 189217.

Clark, A, Oswald, A, \& Warr, P. (1996). Is Job Satisfaction U-shaped in Age? Journal of Occupational and Organizational Psychology, 69, 57-81.

Clark, A. E. (1997). Job satisfaction and gender: why are women so happy at work? Labour Economics, 4 (4), 341-372.

Cron, W. L. \& Slocum, J. W. Jr. (1986) The Influence of career stages on salespeople's job attitudes, work perceptions and performance. Journal of Marketing Research, 23 (2), 119-129.

Eskildsen, J. K, Kristensen, K. \& Westlund, A. (2003). Work motivation and job satisfaction in the Nordic countries. Employee Relations, 26(2), 122-136.

Fako, T. T., Moeng, S. R. T. \& Foreheh, N. (2009). Gender Differences in Satisfaction with the Type of Work University Employees Do: Evidence from the University of Botswana. Journal of Service Science and Management, 2 (4), 404-417.

Farrell, D. (1983). Exit, voice, loyalty, and neglect as responses to job dissatisfaction: A multidimensional scaling study. Academy of Management Journal, 26 (4), 596-607.

Forgionne, G. A. \& Peeters, V. E. (1982). Differences in job motivation and satisfaction among female and male managers. Human Relations, 35 (2), 101-118.

Golembiewski, R. (1977). Testing some stereotypes about the sexes in organizations: differential satisfaction with work? Human Resource Management, 16 (2), 30-32.

Gu Z. \& Chi, R.S.S. (2009). Drivers of job satisfaction as related to work performance in Macao casino hotels: An investigation based on employee survey. International Journal of Contemporary Hospitality Management, 21 (5), 561- 578.

Handyside, J. D. (1961). Satisfactions and aspirations. Occupational Psychology, 35 (4), 213-243.

Herzberg, F., Mausner, B., Peterson, R. O. \& Capwell, D. F. (1957). Job Attitudes: Review of Research and Opinion. Pittsburgh: Psychological Service of Pittsburgh.

Hunt, J. \& Saul, P. (1975). The relationship age, tenure, and job satisfaction in males and females. Academy of Management Journal, 18 (4), 690-702.

Judge, T. A. Thoresen, C. J., Bono, J. E. \& Patton, G. K. (2001). The job satisfaction job performance relationship: A qualitative and quantitative review. Psychological Bulletin, 127 (3), 376-407.

Koys, D. J. (2001). The effects of employee satisfaction, organizational citizenship behavior, and turnover on organizational effectiveness: A unit-level, longitudinal study. Personnel Psychology, 54 (1), 101-114.

Kuzey, C. (2012). Impact of Health Care Employees’ Job Satisfaction On Organizational Performance Support Vector Machine Approach. European Journal of Economic and Political Studies, 5 (1), 65-89.

Latif, M. S., Ahmad, M., Qasim, M., Mushtaq, M., Ferdoos, A., \& Naeem, H. (2013). Impact of employee's job satisfaction on organizational performance. European Journal of Business and Management, 5 (5), 166-171.

Lee, T. H. (2012). Gender differences in voluntary turnover: Still a paradox? International Business Research, 5 (10), 19-28. 
Locke, E. A. (1976). The nature and causes of job satisfaction. In M. D. Dunnette (Ed.), Handbook of Industrial and Organizational Psychology (pp. 1297-1349). Chicago: Rand McNally College Publishing Company.

McShane, S. (2004). Canadian Organizational Behaviour (5th ed.). Toronto: McGraw-Hill Ryerson.

Muchinsky, P.M. (1978). Age and job facet satisfaction: A conceptual reconsideration. Aging and Work, 1, 175-179.

Novak, M. (1993). Aging \& Society: A Canadian Perspective (2nd ed.). Scarborough: Nelson.

Položaj žene u Srbiji u 2014 - činjenice koje demantuju stavove (2014). Retrieved from:http://www.mc.rs/upload/documents/saopstenja_izvestaji/2014/09-25-14Ministarstvo-za-rad.pdf, Accessed on 15 December 2016.

Saleh, S. D. \& Otis, J. L. (1964). Age and job satisfaction. Journal of Personnel Psychology, 17, $425-430$.

Sousa-Poza, A. \& Sousa-Poza, A. A. (2000). Taking another look at the gender/job satisfaction Paradox. Kyklos, 53 (2), 135-52.

Spector, P.E. (1985). Measurement of human service staff satisfaction: Development of the job satisfaction survey. American Journal of Community Psychology, 13(6), 693713.

Spector, P. E. (1997). Job Satisfaction: Application, Assessment, Causes, and Consequences. United Kingdom: Sage Publications Ltd.

Van Saane, N., Sluiter, J.K., Verbeek, H.A.M. \& Frings-Dresen, M.H.W. (2003). Reliability and validity of instruments measuring job satisfaction - a systematic review. Occupational Medicine 53 (3), 191-200.

Wharton, A. S. Rotolo, T., Bird, S. R. (2000) Social context at work: a multilevel analysis of job satisfaction. Sociological Forum, 15 (1), 65-90.

White, A. T., \& Spector, P. E. (1987). An investigation of age-related factors in the age-job satisfaction relationship. Psychology and Aging, 2 (3), 261-265.

Wright, P., McMahan, P. \& McWilliams, A. (1993). Human Resources and Sustained Competitive Advantage: A Resource-Based Perspective. Los Angeles: Center for Effective Organizations-Marshall School of Business.

\section{ODNOS GODINA STAROSTI I POLA ZAPOSLENIH U ORGANIZACIJAMA U REPUBLICI SRBIJI SA NJIHOVIM ZADOVOLJSTVOM POSLOM}

Apstrakt: Cilj ovog rada je da se ispita odnos između godina starosti i pola zaposlenih u organizacijama u Srbiji sa njihovim zadovoljstvom poslom. Kada je reč o odnosu godina starosti i zadovoljstva poslom pretpostavka je da se taj odnos može predstaviti krivom „U“. Kada je u pitanju odnos između pola i zadovoljstva poslom, autori su istraživali da li postoji razlika u ukupnom zadovoljstvu poslom između muškaraca i žena, kao i da li postoji statistički značajan uticaj različitih aspekata posla na zadovoljstvo poslom muškaraca i žena različitih godina $u$ organizacijama $u$ Srbiji. U cilju provere polaznih pretpostavki korišćeni su deskriptivna statistika i multivarijaciona analiza varijanse. Istraživačka metodologija, takođe, je obuhvatila i teorijsku analizu 
koncepta zadovoljstva poslom. Rezultati studije su pokazali da se nivo zadovoljstva poslom zaposlenih različitih godina starosti ne može predstaviti „U“ krivom. Dalje, rezultati su pokazali da postoji mala razlika u ukupnom zadovoljstvu poslom između muškaraca i žena, kao i da postoji neke dimenzije posla koje imaju statistički značajan uticaj na zadovoljstvo poslom muškaraca i žena različite starosti. Praktična implikacija ovog rada ogleda se u tome što se na osnovu dobijenih rezultata menadžerima sugerišu određene prakse menadžmenta ljudskih resursa (MLJR) koje će omogućiti da zaposleni budu zadovoljniji poslom, a time i produktivniji.

Ključne reči: zadovoljstvo poslom, godine starosti, pol, zaposleni, organizacije.

\section{Authors' biographies}

Biljana Đorđević graduated from the Faculty of Economics in Niš in 1992. She received her M.Sc. (1998) and Ph.D. (2007) at the Faculty of Economics in Belgrade. She is Associate Professor at the Faculty of Economics in Niš, teaching the subjects Managing the Enterprises` Resources, Human Resource Management, International Human Resource Management and Career Management. She has published more than eighty scientific and professional papers, the university textbook Human Resource Management (co-author) and monographs Career Success and Managing Human Resources in the Condition of Globalisation (co-author). Her fields of interests include human resource management, career management and international human resource management.

Maja Ivanović Djukić graduated from the Faculty of Economics in Niš in 2000. She recieved her M.Sc. degree (2005) at the Faculty of Economics in Belgrade and a Ph.D. (2009) at the Faculty of Economics Niš. She is Associate Professor at the Faculty of Economics in Niš, teaching the subjects Elements of Management and Management of SME. She has published more than hundred scientific and professional papers, and two monographs. Her fields of interests include management, entrepreneurship, human resource management, CSR.

Vinko Lepojevic is Associate Professor of Statistics at the Faculty of Economics, University of Niš, Serbia. He obtained a M.Sc. degree in Statistics from the Faculty of Economics at the University of Belgrade, and a Ph.D. from Faculty of Economics at the University of Niš, Serbia. His research interests are application of mathematical and statistical methods in economic research and the application of statistical methods in market research. His research papers have been published in international journals and also in the highly regarded national journals. Furthermore, he has presented his research papers at many international conferences. 